\title{
The pros and cons of rent-seeking: Political rent in various research paradigms
}

\begin{abstract}
This article shows that how we look at political rent and rent-seeking depends on our position on state interference in the economy and which theory of regulation we are familiar with. Although the theory of rent-seeking is in accordance with the paradigm of the private interest (economic) theories of regulation, the researcher also needs an insight based on the public interest theories of regulation if he wants to judge the impact of rent-seeking and the creation of political rent on social well-being properly. The paper is also a conceptualization of political rent. It describes forms of rent-seeking and economic systems most amenable to it.
\end{abstract}

Keywords: rent-seeking, rent, predatory state, state capitalism, state capture, regulation JEL Classification Codes: D02, D72, H82, P51

1 Maria Curie-Skłodowska University, Faculty of Economics, Lublin, Poland, e-mail: stefan.sekowski@ poczta.umcs.lublin.pl, https://orcid.org/0000-0002-4777-9205 


\section{Zalety i wady pogoni za rentą. Renta polityczna w różnych paradygmatach badawczych}

\section{Streszczenie:}

Artykuł ukazuje, że to, jak traktujemy rentę polityczną i pogoń za rentą zależy od nastawienia badacza do ingerencji państwa w gospodarkę oraz od tego, jaka teoria regulacji jest mu bliska. Choć teoria pogoni za rentą koresponduje z teorią regulacji opartą na interesie prywatnym (ekonomiczną), badacz musi uwzględnić także podejście bazujące na teorii regulacji opartej na interesie publicznym, jeśli chce właściwie ocenić wpływ pogoni za rentą i kreacji renty politycznej na dobrobyt społeczny. Artykuł zawiera także konceptualizację renty politycznej. Opisuje też różne formy pogoni za rentą i najbardziej podatne na nią systemy ekonomiczne.

Słowa kluczowe: pogoń za rentą, renta, państwo drapieżcze, kapitalizm państwowy, przejmowanie państwa, regulacje

Kody klasyfikacji JEL: D02, D72, H82, P51

There is no dispute that rent-seeking brings various social costs and, generally speaking, is a negative economic category. However, one gets the impression that the authors of various articles or books related to this concept have different phenomena in mind. It seems that at least some of them should have a less negative approach to it if they stack more to their own principles regarding the judgment of regulations or state intervention in the economy. The purpose of this article is to show that the approach to the phenomenon of rent-seeking depends on a broader economic paradigm in which the work of the researcher is rooted and to systematize the terms related to it.

The article consists of three parts. The first one describes and analyzes the concept of political rent. The second part discusses various forms of rent-seeking. The third part examines the relations between various economic systems and the occurrence of the phenomenon of rent-seeking and the creation of political rent. The author will show that the understanding of political rent differs depending on the theory of regulation represented by researchers of this field, which, contrary to appearances, are complementary to each other. 


\section{The phenomenon of rent-seeking: conceptualization}

\section{Classical and contemporary definitions of rent}

In classical economics, rent meant profit not worked out by the owner of a given means of production (Smith, 2007: 118). Most often, it was related to profits (economic benefits) obtained from owned land (Smith, 2007: 43). The classical approach was also based on David Ricardo's (1963: 29) theory of rent. However, nowadays, the concept of rent is usually understood in a broader sense. Robert Solow (2015) wrote on the subject that rent is a return to the special position of companies, not a return earned by labor or capital. Its source may be monopoly power but also protectionism. Anything that hampers competition, sometimes even regulation itself, is a source of rent. Such a broad understanding of rent causes rent to be able to manifest itself in different ways, and as a consequence, various classifications appear in the contemporary literature.

For example, Aage B. Sørensen (2000) divides rents into three groups: (a) monopoly rents - these are rents resulting from social constraints, such as the effect of scale creating high costs of entering the market for others, but also the actions of governments or trade unions; (b) composite rent - this rent is an effect of synergy between two different capitals, for example, the value generated by a water mill is the effect of combining the mill with a rapid stream as a result of which the owner of the mill and the stream owner receive the rent; and (c) rent based on natural abilities and talents - when rent is the result of "free gifts of nature," such as talents or physical conditions useful for performing certain labor. This typology answers the question of whether the receiver of the rent is the sole owner of the source of the rent (monopoly rent), if he or she is sharing it with someone else, or whether we can speak of indivisible but widespread sources.

Péter Mihályi and Iván Szelényi suggest the division of rents into the scarcity rent and solidarity rent. It seems that they differ primarily due to the purpose (or lack thereof) of the occurrence (or cause) of the scarcity. The sources of scarcity rent can be both natural and unnatural monopolies, business innovations, but also monopolies created by the state or regulations limiting market access. This type of rent may appear without a purpose (e.g., with a natural monopoly) but also as a result of an attempt to achieve competitive advantage on the market (innovation) or to obtain an artificially guaranteed privileged position (e.g., licenses). In the case of solidarity rent, the goal of institutions limiting access to a given good is "to create conditions for 
solidarity" (Mihályi and Szelényi, 2019: 54). These types of rents will be, for example, higher wages obtained thanks to the minimum wage or benefits of redistribution.

However, when we read theoretical and empirical papers on rent-seeking, it seems that for their authors it usually does not matter whether a given rent serves or does not serve the common good or whether it is an expression of solidarity. A common feature of the rent described by authors dealing with the topic of rent-seeking is that it is the result of political actions. The division between economic and political rent goes in this direction. It is used, for example, by Jerzy Wilkin (2012: 222). The presented article develops this division. It shows the difference between both types of rent, comparing them with other types which are present in the literature. It also argues that authors writing about rent-seeking have mostly political rent in mind.

\section{Political rent and other rents}

Economic rent results from economic phenomena, such as the monopolistic situation (natural monopoly). Political rent is the one that requires state interference in the economy in order to be achieved. This division should not be confused with the division introduced by Piotr Kozarzewski (2019: 295), who proposes to divide rents obtained through the state into rents of economic nature and of political nature. As economic rents he defines rents that give material benefits to beneficiaries, and as rents of political nature those that meet non-existential needs. Although this division has its own application in a different context, both types of rent in terms of Kozarzewski are included in my definition of political rent.

Imagine a taxi driver who owns his vehicle. If, as a result of a happy (for him) combination of circumstances, he remains the only taxi driver in the city, then he may dictate to customers higher fees that he would not have obtained in a competitive situation. This surplus is an economic rent. However, if he gained his privileged position thanks to a license issued by the authorities that makes him the only taxi driver in town, then we are talking about a political rent.

Although the term political rent is rarely used in the literature on rent-seeking, the context shows that its authors have, in most cases, such a rent in mind. The Tullock rectangle (Tullock, 1967), which has since been considered to illustrate social losses associated with this phenomenon, concerned a situation in which the state is imposing a tariff on a given good. The same applies to the article written by Anne O. Krueger (1974), in which the term rent-seeking appears for the first time. Also, numerous (though not all) definitions of rent-seeking itself introduced by other authors point directly to the relationship of this phenomenon with the actions of the state (Anderson et al., 1988; Rowley, 2000; Tullock, 1980). 
Different definitions of rent are contained within one another or have common parts. Table 1 shows this phenomenon on examples of the relationship between the definitions of Sørensen (2000), Mihályi and Szelényi (2019), and Kozarzewski (2019), and the definitions of economic and political rent presented above. If rent in any of these definitions is included in the definition of economic rent or political rent, it is marked with a (+) sign and, if not included, with a (-) sign. If the definition has parts in common with the definition of economic or political rent, it is marked with a $(\cap)$ sign. An explanation of the common part of both definitions is also attached.

Table 1. Comparison of different concepts of understanding of the term rent

\begin{tabular}{|l|c|c|}
\hline \multicolumn{1}{|c|}{ Types of rent } & Economic rent & Political rent \\
\hline Monopoly rent created naturally (Sørensen, 2000) & + & - \\
\hline Monopoly rent created by social institutions (Sørensen, 2000) & - & $\cap^{\text {a }}$ \\
\hline Scarcity rent, for example, natural monopoly (Mihályi and Szelényi, 2019) & + & $\cap^{\text {b }}$ \\
\hline Scarcity rent, for example, a license (Mihályi and Szelényi, 2019) & - & + \\
\hline Solidarity rent, for example, minimum wage or tariff (Mihályi and Szelényi, 2019) & - & + \\
\hline Solidarity rent, for example, charity institution (Mihályi and Szelényi, 2019) & $\cap^{c}$ & $\cap^{\text {c }}$ \\
\hline Rent of political nature (Kozarzewski, 2019) & - & + \\
\hline Rent of economic nature (Kozarzewski, 2019) & & + \\
\hline
\end{tabular}

${ }^{a}$ If the institution is not supported by the government or some kind of law, for example, the scarcity is caused by low supply or price-fixing.

${ }^{\mathrm{b}}$ If the institution is supported by the government or some kind of law.

${ }^{c}$ If supported voluntarily.

d If supported by the government or some kind of law, for example, a state subvention.

Source: own elaboration.

Despite this, the division of rents into scarcity and solidarity rents is important in the context of the evaluation of a given rent. A rent very rarely - if at all - occurs independently, separated from other forms of benefits that the owner of the means of production obtains. The taxi driver mentioned above drives his clients - therefore, the rent occurs together with profit. This approach may arouse some controversy. Gordon Tullock writes that "My suggestion is that we use the term 'rent seeking' (and I always have) solely for cases in which whatever is proposed has a negative social impact" (Tullock, 1989: 55). In his first article on that topic (Tullock, 1967), he mentioned tariffs not only because they may increase the prices and profits for both the state budget and domestic producers: there are also social costs (or losses) - in the form of products not bought as a result of the necessity to pay higher prices for products with tariffs, as well as the use of funds obtained thanks to tariffs by the state, for example, for construction of tunnels to nowhere (sic!). Tullock assumes that there is a net social loss, i.e., that the cost outweighs the profits of a given political intervention. 
But if we want to get to such a conclusion, we should compare social costs and profits first. Tunnels to nowhere, without benefit for anybody, are seldom built. We can argue whether the investment is effective and whether it could not have been carried out better, but we cannot assume that it is completely wrong purely because it is political. The same applies to regulations. For example, the introduction of the obligation to drive children in car seats was preceded by lobbying on the part of manufacturers, which can be described as rent-seeking. Thanks to the introduction of this regulation, producers receive political rent because they sell more car seats than they would have sold if parents were not obliged to have them. Parents spend on other purposes or save less money because they have already spent them on car seats, which is a social cost. At the same time, hypothetically, fewer deaths or injuries resulting from accidents may be described as a social benefit.

\section{The judgment of rent-seeking}

The approach presented by Tullock and other authors who assume that rent-seeking brings a net social loss (Latkov, 2014) causes some problems when it comes to empirical verification of the theory. In the light of such an assumption, to determine whether we are dealing with rent-seeking we should first determine whether we are dealing with a net social cost. However, this will not be stated if we do not first extract the rent itself and the costs associated with it (including the rent-seeking cost) from other factors such as profit, and subtract it from the hypothetical gains to prove if there is a net social cost.

State interference in the economy is complex in nature. It often brings both good and bad results that are difficult and sometimes impossible to measure economically (and the ability to compare them depends on the purpose of the interference). The separation of phenomena of such similar nature appears to be not very helpful in understanding reality. The more so because it seems that in empirical research on the costs of rent-seeking (Del Rosal, 2011) this problem does not occur. So, either researchers assume in advance that the net social cost of the interference being investigated is negative, or they assume that it does not matter for the results of their research. This would only confirm the correctness of the postulate that the rent should be treated as political, regardless of whether the balance of its appearance (and the seeking of it) is socially positive or negative.

The problem is that when assessing the effects of regulation, two major paradigms compete with each other. Both are focused on anthropological and economic origins of human action, especially political decision-making, and their economic outcomes. Therefore, the paradigms are of political and economic nature. The first 
paradigm sees the state and political decision-makers as people who serve the common good. It "assumes that regulators have sufficient information and enforcement powers to effectively promote the public interest. This tradition also assumes that regulators are benevolent and aim to pursue the public interest" (den Hertog, 2010: 2). Public interest theories of regulation are rooted in that tradition. They treat regulations as impacts on the economy focused on social well-being and assume that regulations are introduced to limit market failures, for example, in situations where externalities or information asymmetry between individual entities occur. Some authors show that the seeking of public interest may be the purpose of creating state-owned enterprises, which is also a form of interfering in the economy (Putniņš, 2015). The theories in this group assume that such interventions benefit society, i.e., there occurs a net social profit.

The second paradigm, which is associated, for example, with the public choice school, assumes that "all economic agents [including political decision makers] pursue their own interest, which may or may not include elements of the public interest. Under these assumptions, there is no reason to conclude that regulation will promote the public interest" (den Hertog, 2010: 2). Economic regulation theories or private interest theories of regulation have their roots in that tradition. They assume that regulations are used by individuals or groups to capture public resources and power to improve their economic situation (Stigler, 1971).

The most fruitful for assessing the effects of state interference in the economy would be the assumption that these two paradigms and groups of theories that are built on them do not compete with but complement each other. In politics, we deal with axiological assumptions, the interests of groups and individuals, as well as the raison d'état, although it is defined differently by individual politicians. It is a convolution that cannot be simplified to state unequivocally that legal and institutional activities are only effects of rent-seeking or are the result of goodwill.

From this perspective, in the rest of the considerations, the term rent will be reduced to political rent, leaving aside issues related to economic rent. (Political) rent will be treated as an individual or group benefit, for whose achievement state interference in the economy is necessary. In turn, rent-seeking is individuals' or groups' pursuit of political rent. This definition applies regardless of whether there is a net benefit or social loss as a result of given state intervention. 


\section{Systemic forms of rent-seeking}

If there can be a "good" and "bad" political rent, depending on our judgment of the social and economic outcome of the interference in the economy, can there also be "good" and "bad" rent-seeking? First of all, it is necessary to distinguish between methods of rent-seeking and systemic forms of rent-seeking. Methods of rent-seeking are a variety of operational activities by which potential beneficiaries seek to obtain different types of political rent (e.g., subsidies, tax breaks, jobs in state-owned enterprises), and they may be legal (e.g., lobbying, social campaigns) and illegal (e.g., corruption).

Various methods of rent-seeking take on an institutionalized form. For a given form to be considered as systemic, no total subordination of the state to the goal of creating and distributing political rent is necessary. It is enough if there are norms that support the creation of political rent and enable it to be obtained by means of various methods of rent-seeking. We can observe this, for example, on the basis of the repetition of the use of various methods or the stability of the type of political rent.

This paper presents five selected systemic forms, whose names appear quite often in the literature. They are also representative of various research paradigms from which the political rent is observed. They do not necessarily bring net social loss, but all of them cause at least some social cost.

\section{Regulatory capture}

It is a form of rent-seeking based on subordinating state regulations to a group or individual interests. This concept is closely related to the economic theory of regulation. As Ernesto Dal Bo (2006: 203) writes: "according to the broad interpretation, regulatory capture is the process through which special interests affect state intervention of any of its forms ... According to the narrow interpretation, regulatory capture is specifically the process through which regulated monopolies end up manipulating the state agencies that are supposed to control them." Regulatory capture is a phenomenon that applies to individual regulations separately. Interest groups employ various methods of rent-seeking to influence politicians to make decisions in accordance with their wishes (to gain political rent). This situation occurs, for example, when the ruling party wants to appeal to a group that is of electoral or financial significance to itself. 


\section{State capture}

Through state capture, interest groups strive to gain decisive influence over so many areas of state influence (law-making, law enforcement, and justice) that one can even talk about its seizure (capture). The term state capture is often used to describe phenomena occurring in countries where there is a close interconnection between political and business elites; they are often even a single camp, bound together with political interest and friendships.

Mihályi and Szelényi (2019) point to the special occurrence of this systemic form of rent-seeking in post-communist countries. They divide it into three different aspects, which in some countries fall into stages: (1) Market capture by political elites. Political elites use state resources to take over public property or secure a privileged position in economic life. (2) State capture by oligarchs - the state was taken over by interest groups as early as the nineteenth century (e.g., in the U.S.), where representatives of industrial elites had a huge impact on legislation. (3) The capture of oligarchs by autocratic rulers - a situation in which economic elites, relatively independent until now, become dependent on persons exercising political power. Selected oligarchs are often charged with corruption or with committing criminal offenses, as a result of which some of them are eliminated from the market, or their political rent is limited.

This typology points to the interdependence between political and business elites. Other authors (Innes, 2013) show that state capture can be exercised for political (party state capture) or economic gain (corporate state capture). The goal of state capture is to transform a state into a perpetual vehicle of rent creation, which minimalizes the rent-seeking cost of the capturer.

\section{Patronage and clientelism}

As Jonathan Hopkin writes, "In very basic terms, political clientelism describes the distribution of selective benefits to individuals or clearly defined groups in exchange for political support. ... Clientelism is a form of personal, dyadic exchange usually characterized by a sense of obligation, and often also by an unequal balance of power between those involved" (Hopkin, 2006: 2). Francis Fukuyama (2014) would divide this understanding of clientelism into two phenomena, depending on whether the beneficiaries are individuals (patronage) or clearly defined groups (clientelism sensu stricto). In his view, the difference between the two phenomena is a matter of scale. "Patronage relations are typically face-to-face ones between patrons and clients and exist in all regimes, whether authoritarian or democratic, whereas clientelism involves 
larger-scale exchanges of favors between patrons and clients, often requiring a hierarchy of intermediaries" (Fukuyama, 2014: 86). On the other hand, "In a clientelistic system, politicians provide individualized benefits only to political supporters in exchange for their votes" (Fukuyama, 2014: 87).

Clientelism occurs in countries where you have to fight for a large number of votes to win the elections. It is used by clientelistic parties, which in his opinion differ from programmatic parties in that they do not mobilize supporters on the basis of an ideological program, but through patronage - clientelist arrangements. An important element of clientelism is that clients receive benefits (political rent) directly.

\section{Client politics (or new clientelism)}

There are indications that at least some researchers treat clientelism and client politics (Baron, 1999; Givens and Luedtke, 2005; Mucciaroni, 1991) as synonyms, others give them different meanings. It seems that in the case of clientelism, benefits go to specific individuals or groups in a targeted manner, and the relationship between electoral votes or funds transferred to the campaign and the benefits is more direct. One can get the impression that the rent transferred to customers is more conditional here - as in the case of direct vote buying, in which the beneficiary must certify that he/she actually supported the politician.

Client politics is aimed at gaining political benefits through rewarding social groups for support but in a less direct way. The conviction that a given political decision can bring electoral benefits may be, for example, the result of social research or intuition, but it does not assume in advance that it is necessary to be supported by those interested in making it. This approach, characterized by a looser relationship between the patron and the client is defined by Jonathan Hopkin (2006) as new clientelism - as opposed to old clientelism, which is closer to Fukuyama's understanding of the concept of clientelism. This new clientelism is also based on more "market" competition for votes.

That definition helps us to describe acts of new clientelism in contemporary politics. For example, in the case of the Polish 500+ program (Magda et al., 2018), the patron can never be completely sure whether he/she will receive "payment" for the "service" in the form of a vote in the next election or whether the competition will not beat him or her with their own promise. Also, the scholar cannot be sure if such a form of political rent brings net social loss. 


\section{Corporate welfare}

Corporate welfare is a situation in which public funds or tax credits are used to support enterprises. The concept was used for the first time, probably in 1956, by Ralph Nader (Ochs, 2010). It was coined in contrast to social welfare - unlike in this case, in corporate welfare the state does not support the poor but large corporations. As Nader writes: "Corporate welfare - the enormous and myriad subsidies, bailouts, giveaways ... and other benefits conferred by government on business - is a function of political corruption. Corporate welfare programs siphon funds from appropriate public investments, subsidize companies ripping minerals from federal lands, ... injure our national security, and weaken our democracy" (Nader, 2000: 10). Here, corporations are receiving political rent not only in the form of subsidies or bailouts. Authors using the term corporate welfare do not only treat various forms of payments or regulations limiting market freedom as symptoms of that phenomena but also, for example, lifting regulations in the interest of companies with potential harm to consumers. This shows how much the understanding of various terms used in the literature or public debate is influenced by the paradigm under which the researcher examines reality. In this case, we can see a large impact of public interest theories of regulation on authors using the term corporate welfare. It might be assumed that they even treat decreasing social welfare as a form of creating political rent. The controversies about this issue will come back when discussing the ambiguity of the concept of a predatory state.

\section{Economic systems and rent-seeking}

Systemic forms of rent-seeking can occur in various economic systems. However, some of them are more liable to rent-seeking than others. There are many categorizations of economic systems, but in the context of interest to us, the division proposed by Paul Dragos Aligica and Vlad Tarko (2012) may be particularly helpful. They mention two contemporary economic systems to be liable to rent-seeking - state capitalism and crony capitalism. Another interesting example is the predatory state, which the author also describes in that context.

\section{State capitalism}

Although the size of the government is not the only factor in the creation of political rent (Aligica and Tarko, 2012: 372), it can be assumed that a greater extent of state interference in the economy gives more opportunities to obtain political 
rent (Mbaku, 1999). The axiological assumption that the state is there to regulate the economy, be an active participant in it, or take part in extensive redistribution, also creates a climate of consent to rent-seeking. This makes the "big" state more susceptible to rent-seeking and willingly creates it.

"State capitalism is an economic system where both the state's functions and the scale of its intervention in the economy are incomparably larger than in liberal economies of free-market capitalism, and state functions, as a rule, significantly go beyond the market failure areas" (Kozarzewski and Bałtowski, 2019). In turn, Joshua Kurlantzik emphasizes state ownership by writing that: "I identify state capitalists as countries whose government has [sic.] an ownership stake in or significant influence over more than one-third of the five hundred largest companies, by revenue, in that country, a situation that gives these governments far greater control over the corporate sector than a government in a more free-market-oriented nation such as the United States or the United Kingdom. Generally, in these state-capitalist countries, the government sees itself as having a direct role to play in managing the economy and guiding the corporate sector" (Kurlantzik, 2016: 9).

As state ownership significantly increases the possibility of intervention in the economy, both definitions can be considered complementary. Aligica and Tarko (2012) show state capitalism not from the point of view of the declared goals of individual interventions or government actions but from the point of view of the benefits obtained by decision-makers. They compare it with mercantilism and real socialism and come to the conclusion that state capitalism is part of a longer trend of the existence of the rent-seeking society - here, the creation and obtaining of political rent is the primary goal of the economic system. On the other side, followers of state intervention point to various benefits of the entrepreneurial state (Mazzucato, 2013). Irrespective of whether state capitalists want to create public or private wealth, the system creates various rent-seeking opportunities. The state which makes its own economic decisions can also make decisions in favor of rent-seekers. Also, a large public sector gives the opportunity to create rents, for example, through the hiring of political allies in state-owned enterprises.

\section{Crony capitalism}

Crony capitalism can be understood as an economic system (Aligica and Tarko, 2014) in which there are close links between political and economic elites, affecting regulations or direct or indirect financial flows to enterprises. In crony capitalism, it seems that clientelism takes on a systemic character: it is not only a practice occurring with varying intensity but a feature constituting political and economic relations. In 
a crony capitalist system, entrepreneurs do not have to be par excellence clients with a relationship of subordination to power. They can be part of the power elite operating in a business segment (and then we cannot talk about clientelism in this context).

Aligica and Tarko (2014) also point out that this system maximizes the available political rent and limits competition in the fight for it, favoring the "cronies" of the current authorities. By increasing costs for entrepreneurs, it increases the social cost of rent-seeking. This feature distinguishes crony capitalism from state capitalism, which does not necessarily have to be "crony." On the other hand, crony capitalism does not place much emphasis on direct state activity in the economy. However, if in such a system the government will outsource a public policy to the private sector, it will be for sure performed out by cronies.

\section{Predatory state}

A state that "concentrates on maximizing rents accruing to the rulers" (Callaghy, 1990: 260) is sometimes called in the literature a predatory state. Douglass North defines it as "the agency of a group or class; its function [is] to extract an income from the rest of the constituents in the interest of that group of class" (North, 1981: 22 as cited by Lundahl, 1997: 31) and Mehrdad Wahabi writes, that "by a predatory state, we mean a state that promotes the private interests of dominant groups within the state (such as politicians, the army and bureaucrats) or influential private groups with strong lobbying powers" (Wahabi, 2020:234). The predatory state is a collective name for all kinds of systems in which the creation of political rent and the seeking of it takes on an institutionalized character and serves to achieve material benefits by the ruling elite. In this sense, a crony capitalist state or a state captured by oligarchs may be defined as a predatory state.

We can say that in the light of the literature on that topic in a predatory state, we can possibly find every form of rent-seeking. But sometimes such an accusation goes probably too far. James K. Galbraith calls the United States of America a predator state and writes that: "[predation is] the systematic abuse of public institutions for private profit." However, in a moment, he adds: "or, equivalently, the systematic undermining of public protections for the benefit of private clients" (Galbraith, 2008: 10). It is worth quoting examples of predation that he gives to understand what he means, for example: "the practice of turning regulatory agencies over to business lobbies, the privatization of national security and the attempted privatization of Social Security, the design of initiatives in Medicare to benefit drug companies" (Galbraith, 2008: 10-11).

Galbraith puts the introduction of new regulations or duties with deregulation or privatization movements side by side. Both are intended to benefit private clients. 
However, in the classic literature dealing with the topic of rent-seeking, only the former would be considered solutions seeking to create political rent. Furthermore, researchers dealing with this topic also looked at deregulation. James M. Buchanan (1980) describes lobbying for deregulation as counter rent-seeking. Its purpose is not to obtain political rent but to avoid the costs associated with potential market regulation. In the light of the literature dealing with this subject, it is impossible to identify both phenomena from the point of view of obtaining political rent.

Reading Galbraith's work according to the terminological key proposed in the first part of the article, it can be said that it tells us about the social benefits that American society does not obtain as a result of deregulation or the lack of regulation. Galbraith leaves the territory of the public choice theory, where the concept of the term was originally created, and used a logic specific to the public interest theory of regulation. This does not mean that his considerations are not at least partly correct, and the conclusions are not authorized. When assessing the effects of regulation, it is also worth considering what potential social benefit is not obtained by giving up regulating a given area. Galbraith also points out that specific groups may be interested in the continued occurrence of various types of market failures, for example, financial institutions or insurance companies with information asymmetry. Although Galbraith does not use this term, one gets the impression that he treats these benefits analogously to the social costs of rent-seeking in the sense of Tullock. However, reversing the meaning of the term predatory state obscures the understanding of this phenomenon and rent-seeking.

\section{Conclusion}

This paper explains the basic terms related to the issue of political rent. An important aspect is to distinguish political rent, which is the result of state intervention in the economy, from economic rent, and also indicates that in the literature on the subject, when rent-seeking is discussed, usually the authors mean political rent. This article describes selected examples of systemic forms of rent-seeking and economic systems particularly susceptible to the creation of political rent or even those in which it is a constitutive feature.

An important aspect is to supplement the issue of political rent with the category of social benefit, which is the reverse of social cost resulting from rent-seeking. The introduction of the notion of social benefit to the topic of political rent indicates that interventions or economic activity of the state are aimed at removing market failures and thus creating social benefits. Only by comparing social benefits and costs can we find out whether we are dealing with a net profit or social loss of the intervention. 
A vast majority of the categories discussed in the article are considered within the paradigm of the public choice theory. However, supplementing the topic of political rent with the concept of social benefit introduces to it a way of thinking close to public interest theories of regulation. This eclecticism is justified by an attempt to show both the potentially negative and potentially positive effects of state interference in the economy. The author is aware of the dangers of combining two paradigms. He points out the necessity of complementing both theories, while also emphasizing the need for a demarcation line between them.

The article describes not all systemic forms of rent-seeking or political systems friendly for rent-seeking. Describing them in this context requires further research. It can also be a starting point for empirical research on both forms and systems, as well as seeking a balance between costs and social benefits resulting from state interference in the economy, which results in the creation of political rent.

\section{References}

Aligica, P.D., Tarko, V. (2012). State capitalism and the rent-seeking conjecture. Constitutional Political Economy, 23: 357-379. DOI: 10.1007/s10602-012-9128-1

Aligica, P.D., Tarko, V. (2014). Crony Capitalism: Rent Seeking, Institutions and Ideology. Kyklos, 67(2): 156-176. DOI: 10.1111/kykl.12048

Anderson, G.M., Rowley, C K., Tollison, R.D. (1988). Rent-Seeking and the Restriction of Human Exchange. The Journal of Legal Studies, 17(1): 83-100. DOI: 10.1086/468122

Baron, D.P. (1999). Integrated Market and Nonmarket Strategies in Client and Interest Group Politics. Business and Politics, 1(1): 7-34. DOI: 10.1515/bap.1999.1.1.7

Buchanan, J.M. (1980). Rent Seeking and Profit Seeking, In: J. M, Buchanan, R.D., Tollison, G. Tullock, (Eds.), Toward a theory of the rent-seeking society: 3-15. College Station, Texas: Texas A\&M University Press.

Callaghy, T.M. (1990). Lost Between State And Market: The Politics of Economic Adjustment in Ghana, Zambia and Nigeria. In: J.M. Nelson (Ed.), Economic Crisis and Policy Choice. The Politics of Adjustment in the Third World: 257-319. Princeton, NJ: Princeton University Press.

Dal Bo, E. (2006). Regulatory capture: A review. Oxford Review of Economic Policy, 22(2): 203-225. DOI: 10.1093/oxrep/grj013

Del Rosal, I. (2011). The Empirical Measurement of Rent Seeking Costs. Journal of Economic Surveys, 25(2): 298-325. DOI: 10.1111/j.1467-6419.2009.00621.x

Galbraith, J.K. (2008). The Predator State: How Conservatives Abandoned the Free Market and Why Liberals Should Too. New York, NY: Free Press.

Givens, T. Luedtke, A. (2005). European Immigration Policies in Comparative Perspective: Issue Salience, Partisanship and Immigrant Rights. Comparative European Politics, 3: 1-22. DOI: $10.1057 /$ palgrave.cep.6110051 
Hertog den, J. (2010). Review of Economic Theories of Regulation. Working Papers, Utrecht School of Economics Tjalling C. Koopmans Research Institute Discussion Paper Series, 10-18. Retrieved from: https://dspace.library.uu.nl/bitstream/handle/1874/309815/10_18. pdf (accessed: 11.3.2021).

Hopkin J. (2006). Conceptualizing political clientelism: Political exchange and democratic theory. Paper prepared for APSA annual meeting, "Concept analysis: Unpacking clientelism, governance and neoliberalism," London. Retrieved from: http://personal.lse.ac.uk/HOPKIN/ apsahopkin2006.pdf (accessed: 11.3.2021).

Fukuyama, F. (2014). Political Order and Political Decay. From the Industrial Revolution to the Globalisation of Democracy. New York, NY: Farrar, Straus and Giroux.

Innes A. (2013). The Political Economy of State Capture in Central Europe. Journal of Common Market Studies, 52(1): 88-104.

Kozarzewski, P. (2019). Polityka właścicielska państwa w okresie transformacji systemowej. Próba syntezy. Lublin: UMCS.

Kozarzewski, P., Bałtowski, M. (2019). State Capitalism in Poland. Conference Presentation: The EACES workshop 'The Rise of State Capitalism: Consequences for Economic and Political Development,' Moscow, 10-11 April 2019. Retrieved from: https://www.researchgate.net/ publication/332738522_State_Capitalism_in_Poland (accessed: 11.3.2021).

Krueger, A.O. (1974). The Political Economy of the Rent-Seeking Society. The American Economic Review, 64(3): 291-303.

Kurlantzick, J. (2016). State Capitalism, Oxford: Oxford University Press. Kindle Edition.

Latkov, A. (2014). Trends of Rent-Seeking Theory. MPRA Paper 62865. October. Munich Personal RePEc Archive. Retrieved from: https://mpra.ub.uni-muenchen.de/62864/1/ MPRA_paper_62864.pdf (accessed: 12.3.2021).

Lundahl, M. (1997). Inside the Predatory State: The rationale, methods, and economic consequences of kleptocratic regimes. Nordic Journal of Political Economy, 24: 31-50.

Magda I., Kiełczewska A., Brandt, N. (2018), The "family 500+" child allowance and female labour supply in Poland, OECD Economics Department Working Papers, No. 1481, OECD Publishing, Paris. DOI: 10.1787/1a30745e-en.

Mazzucato, M. (2013). The Entrepreneurial State: Debunking Public vs. Private Sector Myths, London, UK; New York, NY: Anthem Press.

Mbaku, J.M. (1999). Corruption cleanups in developing societies: the public choice perspective. International Journal of Public Administration, 22(2): 309-345. DOI: 10.1080/01900 699908525385

Mihályi, P., Szelényi, I. (2019). Rent-Seekers, Profits, Wages and Inequality: The Top 20\%, Cham: Palgrave Pivot.

Mucciaroni, G. (1991). Unclogging the Arteries: The Defeat of Client Politics and the Logic of Collective Action. Policy Studies Journal, 19 (3-4): 474-494. DOI: 10.1111/j.15410072.1991.tb00422.x

Nader, R. (2000). Cutting Corporate Welfare, Seven Stories Press, New York, NY. 
North, D.C. (1981). Structure and Change in Economic History, W.W. Norton, New York, NY, and London.

Ochs, H.L. (2010), Corporate Welfare, In: R. Chapman (Ed.), Culture Wars: An Encyclopedia of Issues, Viewpoints, and Voices: 119. Armonk, NY: Myron E. Sharpe.

Putniņš, T.J. (2015). Economics of State-Owned Enterprises. International Journal of Public Administration, 38(11): 815-832. DOI: 10.1080/01900692.2014.982289

Ricardo, D. (1963). The Principles of Political Economy and Taxation, Homewood, IL, Richard D. Irwin Inc.

Rowley, C.K. (1988). Rent-Seeking Versus Directly Unproductive Profit-Seeking Activities. In: C.K. Rowley, R.D. Tollison, G. Tullock (Eds.), The Political Economy of Rent Seeking: 15-25. New York, NY: Springer Science+Business Media.

Rowley, C.K. (2000). Political Culture and Economic Performance in Sub-Saharan Africa. European Journal of Political Economy, 16(1): 133-158. DOI: 10.1016/S0176-2680(99)00051-8

Smith A. (2007). An Inquiry into the Nature and Causes of the Wealth of Nations. S.M. Soares (Ed.). Amsterdam, Lausanne, Melbourne, Milan, New York, NY, Sao Paolo: MeataLibri Original Library. Retrieved from: http://www.ibiblio.org/ml/libri/s/SmithA_Wealth Nations_p.pdf (accessed: 12.3.2021).

Solow, R. (2015, Aug). The Future of Work: Why Wages Aren't Keeping Up?. Pacific Standard,11. Retrieved from: https://psmag.com/economics/the-future-of-work-why-wages-arentkeeping-up (accessed: 12.3.2021).

Sørensen, A.B. (2000). Toward a Sounder Basis for Class Analysis. American Journal of Sociology, 105(6), 1523-1558. DOI: 10.1086/210463

Stigler, G. (1971). The Theory of Economic Regulation. The Bell Journal of Economics and Management Science, 2(1): 3-21.

Tullock, G. (1967). The Welfare Cost of Tariffs, Monopolies, and Theft. Western Economic Journal, 5(3), 224-232. DOI: 10.1111/j.1465-7295.1967.tb01923.x

Tullock, G. (1980). Efficient Rent-Seeking. In: J.M., Buchanan, R.D., Tollison G. Tullock (Eds.), Toward a Theory of the Rent-Seeking Society: 97-112. College Station, Texas: Texas A\&M University Press.

Tullock, G. (1989). The Economics of Special Privilege and Rent-Seeking. Boston, MA, Dordrecht, London: Kluwer Academic Publishers.

Wahabi, M. (2020). Introduction: a symposium on the predatory state. Public Choice, 182: 233-242. DOI: 10.1007/s11127-019-00715-2

Wilkin, J. (2012). Pogoń za rentą za pomocą mechanizmów politycznych (Rent-seeking via political mechanisms), In: J. Wilkin (Ed.), Teoria wyboru publicznego. Główne nurty i zastosowania: 221-237. Warszawa: Scholar.

Unless stated otherwise, all the materials are available under the Creative Commons Attribution 4.0 International license. Some rights reserved to SGH Warsaw School of Economics.

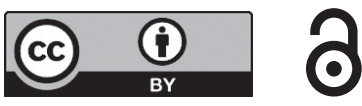

